\title{
Chemical and ruminal in vitro evaluation of Canadian canola meals produced over 4 years ${ }^{1}$
}

\author{
Glen A. Broderick, ${ }^{* 2,3}$ Stefania Colombini, $†$ Sara Costa, $†$ Mehmet A. Karsli,‡ and Antonio P. Faciola§ \\ *Agricultural Research Service, USDA, US Dairy Forage Research Center, 1925 Linden Drive, Madison, WI 53706 \\ †Dipartimento di Scienze Animali, Università degli Studi di Milano, Milan, 20133 Italy \\ łDepartment of Animal Nutrition, Veterinary Faculty, Kirikkale University, 71451 Turkey \\ §Department of Agriculture, Nutrition, and Veterinary Science, University of Nevada, Reno 89557
}

\begin{abstract}
To test the effects of year and processing plant on the nutritional value of canola meal (CM), 3 CM samples/ yr were collected from each of 12 Canadian production plants over $4 \mathrm{yr}($ total $=144)$. Samples of $\mathrm{CM}$ were analyzed for differences in chemical composition and for in vitro ruminal protein degradability using the Michaelis-Menten inhibitor in vitro (MMIIV) method. In the MMIIV method, protein degradation rate $\left(\mathrm{k}_{\mathrm{d}}\right)$ was estimated by 2 methods: from net release (i.e., blank corrected) of (1) ammonia plus AA determined by $o$-phthaldialdehyde fluorescence $\left(\mathrm{OPA}_{\mathrm{F}}\right)$ assay or (2) ammonia, AA, plus oligopeptides determined by $o$-phthaldialdehyde absorbance $\left(\mathrm{OPA}_{\mathrm{A}}\right)$ assay; rumenundegradable protein (RUP) was computed assuming passage rates of 0.16 and $0.06 / \mathrm{h}$ for, respectively, soluble and insoluble protein. Casein, solvent soybean meal (SSBM), and expeller soybean meal (ESBM) were included in all incubations as standard proteins. Differences among years and plants were assessed using the mixed procedures of SAS. Small but significant differences were found in CM among years for chemical composition, including $\mathrm{N}$ solubility; some of these differences may have been related to changes in our analytical methods over time. However, adjustment of degradation activity of individual in vitro incubations based on the mean degradation activity over all incubations yielded $\mathrm{k}_{\mathrm{d}}$ and RUP that did not differ by year using either assay. Simultaneously incubating CM samples from $2 \mathrm{yr}$ in the same in vitro runs confirmed that no year effects existed for $k_{d}$ or RUP. Differences
\end{abstract}

\footnotetext{
Received February 8, 2016

Accepted June 6, 2016.

${ }^{1}$ Mention of any trademark or proprietary product in this paper does not constitute a guarantee or warranty of the product by the USDA or the Agricultural Research Service and does not imply its approval to the exclusion of other products that also may be suitable.

${ }^{2}$ Retired; present address: Broderick Nutrition and Research LLC, 221 Glen Hollow Road, Madison, WI 53705.

${ }^{3}$ Corresponding author: gbroderi@wisc.edu
}

existed in chemical composition of CM among the 12 processing plants over the $4 \mathrm{yr}$ of sample collection. Moreover, consistent differences in $\mathrm{k}_{\mathrm{d}}$ and RUP were observed among plants: $\mathrm{k}_{\mathrm{d}}$ ranged from 0.069 to $0.113 / \mathrm{h}$ $\left(\mathrm{OPA}_{\mathrm{A}}\right.$ assay) and 0.075 to $0.120 / \mathrm{h}\left(\mathrm{OPA}_{\mathrm{F}}\right.$ assay), and RUP estimates ranged from 51 to $43 \%\left(\mathrm{OPA}_{\mathrm{A}}\right.$ assay) and 49 to $41 \%$ ( $\mathrm{OPA}_{\mathrm{F}}$ assay). Regression of $\mathrm{k}_{\mathrm{d}}$ on insoluble $\mathrm{N}$ content of $\mathrm{CM}$ yielded correlation coefficients $\left(\mathrm{R}^{2}\right)=0.40\left(\mathrm{OPA}_{\mathrm{A}}\right.$ assay $)$ and $0.42\left(\mathrm{OPA}_{\mathrm{F}}\right.$ assay $)$, and regressions of $\mathrm{k}_{\mathrm{d}}$ on NDIN and $\mathrm{N}$-fraction $\mathrm{B}_{3}$ yielded $\mathrm{R}^{2}<0.02$. Mean estimates from both $\mathrm{OPA}_{\mathrm{A}}$ and $\mathrm{OPA}_{\mathrm{F}}$ assays for casein, SSBM, ESBM, and CM were, respectively, $\mathrm{k}_{\mathrm{d}}=0.764,0.161,0.050$, and $0.093 / \mathrm{h}$ and RUP $=18,33,56$, and $45 \%$. A range of 8 percentage units from lowest to highest RUP suggests that substantial differences exist in metabolizable protein content of CM produced by different processing plants.

Key words: canola meal, chemical composition, ruminal degradation, rumen-undegraded protein

\section{INTRODUCTION}

Increased production of canola has resulted in greater availability of canola meal (CM) as an alternative to soybean meal (SBM) for protein supplementation of lactating dairy cows (Hickling, 2008). Meta-analyses of published findings showed that replacing SBM with CM significantly increased milk protein yield (Martineau et al., 2013) and increased feed intake and yield of milk and milk components (Huhtanen et al., 2011). We observed numeric increases in milk and protein yield when CM replaced supplemental protein from SBM in $16.5 \% \mathrm{CP}$ diets in dairy cows (Brito and Broderick, 2007). Brito et al. (2007) found that the proportion of RUP in CM was numerically greater than that in SBM. Huhtanen et al. (2011) also concluded that CM contributed amounts of RUP and MP that were at least equal to SBM. Ruminal in situ studies conducted by Maxin et al. (2013a) showed that SBM had a more rapid degradation rate, higher effective degradability, and lower RUP than CM. More recently (Broderick et al., 2015), 
increased DMI and yield of milk and milk protein were associated with reduced ruminal concentrations of ammonia and branched-chain VFA in cows fed CM versus SBM, suggesting lower ruminal degradation of $\mathrm{CM}$ protein. The National Research Council (NRC, 2001) model indicates ruminal protein degradation rates of $7.5 \% / \mathrm{h}$ for $48 \% \mathrm{SBM}$ and $10.4 \% / \mathrm{h}$ for CM, and RUP values of $43 \%$ for $48 \% \mathrm{SBM}$ and $36 \%$ for $\mathrm{CM}$ (at DMI $=$ $4 \%$ of BW with $50 \%$ dietary DM fed as forage). These NRC (2001) data appear to be inconsistent with the greater RUP in CM reported by Maxin et al. (2013a) and the reduced ruminal ammonia and branched-chain VFA concentrations observed by Broderick et al. (2015) when CP from CM replaced equal CP from SBM.

Other evidence indicates that CM may be a more effective protein supplement than certain byproduct feeds such as distillers dried grains plus solubles (DDGS): Swanepoel et al. (2014) observed that replacing corn DDGS with CM increased both milk and true protein yield. Although milk and protein yield were not different, Acharya et al. (2015) found that replacing corn DDGS with CM significantly improved efficiency of MP utilization. Mutsvangwa et al. (2016) reported that substituting CM for wheat DDGS gave a numeric yield increase of $1.1 \mathrm{~kg}$ of milk/d plus increased omasal flow of Thr and Trp and tended to increase omasal flow of His and Lys.

Growing conditions experienced in canola production vary substantially from year to year, and we speculated that these differences might alter the nutritional quality of CM for ruminants. Therefore, the objectives of this study were to (1) determine if year of CM production had a significant effect on chemical composition and ruminal protein degradability; (2) determine if CM production plant led to significant differences in chemical composition and ruminal protein degradability; and (3) assess the relative ruminal degradability of protein in $\mathrm{CM}$ and SBM.

\section{MATERIALS AND METHODS}

\section{Protein Samples}

Canola meal samples were collected over 4 yr (2011, 2012, 2013, and 2014), 3 per year, from each of 12 Canadian canola processing plants (total $=144$ samples). The 12 plants accounted for the entire CM production in Canada when the studies began; however, a 13th plant has recently come online. About $80 \%$ of the CM produced in North America derives from these plants (Carson Callum, Canola Council of Canada, Winnipeg, MB, personal communication). At 11 plants, oil was removed from crushed canola seed by prepress solvent extraction; oil was removed by expeller extraction at
1 plant. The $144 \mathrm{CM}$ samples were identified by plant number (1-12), production year (2011-2014), and replicate within year (1-3). Prior to chemical and in vitro analysis, samples were ground using a laboratory mill fitted with a 1-mm screen (Udy cyclone mill, Udy Corporation, Fort Collins, CO). Three standard proteins were also included in all in vitro incubations: casein (no. C-5890, Sigma Chemicals, St. Louis, MO), solventextracted SBM (SSBM), and expeller-extracted SBM (ESBM). These same standard proteins had been incubated in earlier in vitro studies (Colombini et al., 2011).

\section{Donor Animals and Diets}

Ruminal inocula used in the incubations were obtained from 2 lactating Holstein donor cows surgically fitted with ruminal cannulas (Bar Diamond, Parma, ID) and fed a diet composed of $40 \%$ alfalfa silage, $20 \%$ corn silage, $31.3 \%$ ground shelled corn, $8.0 \%$ SSBM, $0.4 \%$ sodium bicarbonate, and $0.2 \%$ salt plus vitamins and trace minerals (on a DM basis) and formulated to $16.5 \% \mathrm{CP}$ and $1.6 \mathrm{Mcal} \mathrm{NE}_{\mathrm{L}} / \mathrm{kg} \mathrm{DM}$ (at $3 \times$ maintenance; NRC, 2001). About 5 min elapsed between collection of inocula and the start of strained ruminal fluid (SRF) pre-incubation for incubations conducted in 2011, 2013, and 2014. The University of Wisconsin facility housing donor animals was not available in 2012, necessitating that donor animals be maintained at the US Dairy Forage Research Center farm, which is $40 \mathrm{~km}$ from the laboratory. Thus, inocula used in incubations conducted in 2012 were obtained from 2 lactating Holstein donor cows, similarly fitted with ruminal cannulas and fed the same basal diet; however, about $50 \mathrm{~min}$ elapsed between collection of inocula and the start of SRF pre-incubations. Surgical care and general maintenance of the animals was as outlined by the guidelines of the University of Wisconsin institutional animal care and use committee.

\section{Chemical Analysis}

The CM samples were chemically analyzed in duplicate during the year of collection. Composition data of the 3 standard proteins (casein, SSBM, and ESBM) determined in 2011 were used in computations over all 4 yr. All samples were analyzed for total N (Leco FP2000 N Analyzer; Leco Instruments, Inc., St. Joseph, MI), DM (method 967.03; AOAC, 1990), ash and OM (method 942.05; AOAC, 1990), sequentially for NDF, ADF, and ADIN using heat stable $\alpha$-amylase and $\mathrm{Na}_{2} \mathrm{SO}_{3}$ (Van Soest et al., 1991; Hintz et al., 1996), and for NDIN omitting $\alpha$-amylase and $\mathrm{Na}_{2} \mathrm{SO}_{3}$ during 
extraction (Licitra et al., 1996). All samples (except casein) were analyzed for buffer insoluble and soluble $\mathrm{N}$ using the method of Licitra et al. (1996) with the following modifications: McDougall's buffer (McDougall, 1948) was used for extractions, extracts were filtered through Whatman no. 41 ashless filter paper, insoluble $\mathrm{N}$ was determined by combustion (Leco FP-2000) as the difference between the filter plus the retained residue and filter only; the percentage of soluble $\mathrm{N}$ was computed as 100 minus insoluble N.

The proportion of total $\mathrm{N}$ already degraded at $t=0$ $\left(\mathbf{F D}_{0}\right)$ was originally determined in the year of collection by weighing duplicates of $100 \mathrm{mg}$ of each protein into $50-\mathrm{mL}$ centrifuge tubes and then adding $15 \mathrm{~mL}$ of warm $\left(39^{\circ} \mathrm{C}\right) \mathrm{McDougall}$ 's buffer. Samples were swirled and incubated with shaking in the warm room $\left(39^{\circ} \mathrm{C} \pm\right.$ $0.5)$ for $2 \mathrm{~h}$. At the end of the buffer-only extraction, $1.25 \mathrm{~mL}$ of $65 \%$ (wt/vol) trichloroacetic acid (TCA) was added (final concentration 5\% wt/vol TCA) and tubes were placed on ice. After $30 \mathrm{~min}$, about $4 \mathrm{~mL}$ of sample from each extraction tube was decanted into a 12 - by $75-\mathrm{mm}$ plastic tube, and tubes were centrifuged (15 min, $14,000 \times g$ and $4^{\circ} \mathrm{C}$ ). Supernatants were then transferred to clean tubes and stored at $4^{\circ} \mathrm{C}$ until analyzed the following day for ammonia, total AA (TAA), and TAA plus oligopeptides as described below. Content of $\mathrm{FD}_{0}$ in all 144 samples also was reanalyzed in duplicate in 2014 using the procedure just described. The TAA content of proteins $(\mu \mathrm{mol} / \mathrm{mg}$ of $\mathrm{N})$ were determined by hydrolyzing duplicate samples of each protein in $6 \mathrm{~N} \mathrm{HCl}$ for $24 \mathrm{~h}$ at $105^{\circ} \mathrm{C}$ under a $\mathrm{N}_{2}$ atmosphere, using a ratio of $1 \mathrm{mg}$ of sample $\mathrm{N} / 5 \mathrm{~mL}$ of acid (Block and Weiss, 1956). After hydrolysis, samples were cooled and diluted with distilled water, $\mathrm{HCl}$ was removed by vacuum evaporation (Savant SC110 Speedvac Concentrator, Savant Instruments, Inc., Farmingdale, NY), and the residues were redissolved in distilled water and re-evaporated. Residues were then dissolved in $4 \mathrm{~mL}$ of $0.10 \mathrm{~N} \mathrm{HCl}$ and stored $\left(-20^{\circ} \mathrm{C}\right)$ for later analysis.

\section{In Vitro Protocol}

Incubations were conducted using the MichaelisMenten inhibitor in vitro method (MMIIV) described by Colombini et al. (2011). All proteins were weighed to the nearest $0.0001 \mathrm{~g}$ into $50-\mathrm{mL}$ centrifuge tubes in amounts equivalent to 2.5, 5.0, 10.0, 20.0, and 30.0 $\mathrm{mg}$ of $\mathrm{N} /$ tube. Whole ruminal contents were collected from beneath the fibrous mat in the rumen and filtered at the barn through 2 layers of cheesecloth into insulated bottles that had flushed previously with $\mathrm{CO}_{2}$ to remove the air. These filtrates were transported to the laboratory in about $5 \mathrm{~min}(2011,2013,2014)$ or about 50 min (2012) and then filtered again through 4 layers of cheesecloth; equal volumes of SRF from each cow were mixed together. To each $1 \mathrm{~L}$ of SRF, a solution containing $8 \mathrm{~g}$ of maltose (Sigma no. M-2250), 4 $\mathrm{g}$ of xylose (Sigma no. X-1500), $4 \mathrm{~g}$ of soluble starch (Sigma no. S-2004), and $2.5 \mathrm{~g}$ of $\mathrm{NaHCO}_{3}$ dissolved in $150 \mathrm{~mL}$ of distilled water, plus a solution containing 4 $\mathrm{g}$ of citrus pectin (Sigma no. P-9135) dissolved with heating and slow stirring into $150 \mathrm{~mL}$ of McDougall's buffer, were added (total volume $1.30 \mathrm{~L}$ ). Then, $0.2 \mathrm{~mL}$ of the surfactant Antifoam 204 (Sigma no. A-6426) was added, and the inoculum was pre-incubated at $39^{\circ} \mathrm{C}$ for $3 \mathrm{~h}$ under a continuous $\mathrm{CO}_{2}$ stream. Every hour, $\mathrm{pH}$ was measured; if $\mathrm{pH}$ was $\leq 6.2, \mathrm{pH}$ was adjusted to 6.4 by slow addition with stirring of $3 \mathrm{~N} \mathrm{NaOH}$. Inhibitor solutions (Broderick, 1987) were prepared by dissolving with stirring $0.267 \mathrm{~g}$ of hydrazine sulfate (Sigma no. $\mathrm{H}-7394)$ in $35 \mathrm{~mL}$ of McDougall's buffer and $0.062 \mathrm{~g}$ of chloramphenicol (Sigma no. C-0378) in $35 \mathrm{~mL}$ of McDougall's buffer. Addition of these 2 solutions to the $1.30 \mathrm{~L}$ of pre-incubated medium yielded $1.37 \mathrm{~L}$ of inoculum containing $1.5 \mathrm{~m} M$ hydrazine sulfate and 45 $\mathrm{mg}$ of chloramphenicol/L. Mercaptoethanol (Sigma no. M-6250) was then added $(0.321 \mathrm{~mL})$ as a reducing agent to give $3 \mathrm{~m} M$ mercaptoethanol in the inoculum.

While the inoculum was pre-incubating, $5 \mathrm{~mL}$ of warm $\left(39^{\circ} \mathrm{C}\right)$ McDougall's buffer was added to each incubation tube to suspend all proteins in buffer for 1 $\mathrm{h}$ before the start of the incubation. Incubations were begun by dispensing $10 \mathrm{~mL}$ of inoculum/tube; immediately after inoculum addition, tube headspace was flushed with $\mathrm{CO}_{2}$, and tubes were capped, swirled, and incubated for $2 \mathrm{~h}$ at $39^{\circ} \mathrm{C}( \pm 0.5)$ in a warm room under continuous mixing with a wrist-arm shaker (set at 100 cycles $/ \mathrm{min}$ ). At the end of the incubation, $1.25 \mathrm{~mL}$ of TCA $(65 \% \mathrm{wt} / \mathrm{vol})$ was added to each tube and tubes were placed on ice for $30 \mathrm{~min}$. Next, about $4 \mathrm{~mL}$ of sample from each incubation tube was decanted into a 12 - by $75-\mathrm{mm}$ plastic tube, and tubes were centrifuged $\left(15 \mathrm{~min}, 14,000 \times g\right.$ and $\left.4^{\circ} \mathrm{C}\right)$. Supernatants were then transferred to clean tubes, which were stored at $4^{\circ} \mathrm{C}$ until analyzed the following day as described in the following section. Duplicate blank tubes were included before and after every 40 protein-containing tubes, and incubations typically consisted of 200 to 220 tubes. Incubations of samples from 2011, 2012, and 2013 were replicated 3 times and contained all CM collected in each respective year. Samples collected in 2014, plus those collected in 2013, were run in 6 incubations, with half of the CM from each year included in 3 incubations and the other half included in the other 3 incubations. The 2 replicate observations made for the $2013 \mathrm{CM}$ were averaged to yield 3 rather than 6 incubation observations per CM sample for statistical analysis. 
Only the ESBM standard protein was included in the incubations conducted with CM from 2011; all 3 standard proteins were included in incubations conducted with CM collected in 2012, 2013, and 2014.

\section{Determination of Ammonia, TAA, and TAA plus Oligopeptides}

Protein hydrolysates and TCA supernatants (from $\mathrm{FD}_{0}$ extractions and in vitro incubations) were analyzed for ammonia by a phenol-hypochlorite assay adapted to a flow injection analyzer (Lachat QuickChem 8000 FIA; Lachat Instruments, Loveland, CO). The o-phthalaldehyde (OPA) reaction (Roth, 1971), based on fluorescence from excitation at $340 \mathrm{~nm}$ and emission at $450 \mathrm{~nm}\left(\mathbf{O P A}_{\mathbf{F}}\right.$; TAA) or on absorbance at $340 \mathrm{~nm}\left(\mathbf{O P A}_{\mathbf{A}}\right.$; TAA + oligopeptides), was applied to all samples. Those analyses were conducted by flow injection analyzer (Lachat Quick-Chem 8000 FIA) interfaced with a fluorimeter (FS-950 Fluoromat; Kratos Analytical Instruments, Westwood, NJ) for fluorescence $\left(\mathrm{OPA}_{\mathrm{F}}\right.$ assay) and modified with an UV light source (AIS D-1000; Analytical Instrument Systems, Flemington, NJ) for absorbance at $340 \mathrm{~nm}\left(\mathrm{OPA}_{\mathrm{A}}\right.$ assay).

The $\mathrm{FD}_{0}$ values measured by the $\mathrm{OPA}_{\mathrm{A}}$ method averaged about $7 \%$ of total $\mathrm{N}$, but those determined by the $\mathrm{OPA}_{\mathrm{F}}$ method averaged only about $2 \%$; previously, $\mathrm{FD}_{0}$ values determined for SSBM and ESBM were found to be $<2 \%$ by both $\mathrm{OPA}_{\mathrm{A}}$ and $\mathrm{OPA}_{\mathrm{F}}$ assays (Colombini et al., 2011). This difference was due to a compound (or compounds) in both CM sample extracts and hydrolysates that contributed to $\mathrm{A}_{340}$. Initially, $\mathrm{A}_{340}$ was measured twice in all buffer extracts, hydrolysates, and in vitro incubations, both with and without OPA reagent in the reaction stream, and the net difference between these values was considered the $\mathrm{A}_{340}$ contributed by TAA and oligopeptides. Subsequently, $\mathrm{FD}_{0}$ values measured using either $\mathrm{OPA}_{\mathrm{A}}$ or $\mathrm{OPA}_{\mathrm{F}}$ were found to not differ $(P=0.26)$, and data obtained directly by $\mathrm{OPA}_{\mathrm{A}}$ were used as obtained (i.e., without correcting for $\mathrm{A}_{340}$ detected in the absence of OPA reagent). This approach obviated the need for analyzing samples both with and without OPA reagent.

All computations and nonlinear regression of extents of protein degradation on amount of protein incubated were conducted using the Michaelis-Menten model and methodology described earlier (Broderick and Clayton, 1992; Colombini et al., 2011). Extent of protein degraded $\left(\mathrm{S}_{\mathrm{D}}, \mathrm{mg} \mathrm{N} / \mathrm{mL}\right.$ inoculum) was computed at each level of $\mathrm{N}$ addition from net release of $\mathrm{N}$ as ammonia plus TAA (and oligopeptides) determined using either the $\mathrm{OPA}_{\mathrm{F}}$ or the $\mathrm{OPA}_{\mathrm{A}}$ assay with the following equation:

$$
\mathrm{S}_{\mathrm{D}}=\left\{\begin{array}{l}
\left(\left[\mathrm{NH}_{3}\right]_{\text {prot }}-\left[\mathrm{NH}_{3}\right]_{\text {blank }}\right) \times 0.0140067 \\
+\left([\mathrm{TAA}]_{\text {prot }}-[\mathrm{TAA}]_{\text {blank }}\right) /(\mathrm{TAA} / \mathrm{N})
\end{array}\right\} \times 16.25 / 10
$$

where $\left[\mathrm{NH}_{3}\right]_{\text {prot }}$ and $\left[\mathrm{NH}_{3}\right]_{\text {blank }}$ and $[\mathrm{TAA}]_{\text {prot }}$ and $[\mathrm{TAA}]$ blank are concentrations of ammonia and TAA ( $\mu \mathrm{mol} /$ $\mathrm{mL}$ ) determined by either $\mathrm{OPA}_{\mathrm{A}}$ or $\mathrm{OPA}_{\mathrm{F}}$ in proteincontaining and blank incubation tubes, respectively; 0.0140067 is the $\mathrm{mg}$ of $\mathrm{N} / \mu \mathrm{mol}$ of ammonia; TAA/ $\mathrm{N}$ is the ratio of TAA (determined by acid hydrolysis of proteins using either $\mathrm{OPA}_{\mathrm{A}}$ or $\left.\mathrm{OPA}_{\mathrm{F}}\right)$ to total $\mathrm{N}(\mu \mathrm{mol} / \mathrm{mg}$ of N); 16.25 (i.e., $15+1.25$ ) is the total tube volume $(\mathrm{mL})$; and 10 is the volume $(\mathrm{mL})$ of added SRF inoculum. Velocity of protein degradation $[\mathrm{v}, \mathrm{mg} \mathrm{N} /(\mathrm{h} \cdot \mathrm{mL}$ inoculum)] was also computed for each protein source at each level of $\mathrm{N}$ by dividing the extent of protein degradation $\left(\mathrm{S}_{\mathrm{D}}\right)$, computed using either TAA assay, by incubation time, $t(2 \mathrm{~h})$ :

$$
\mathrm{v}=\mathrm{S}_{\mathrm{D}} / 2 \text {. }
$$

Protein $\mathrm{N}$ remaining undegraded at the end of the incubation for each amount of added $\mathrm{N}\left(\mathrm{S}_{t}, \mathrm{mg}\right.$ of $\mathrm{N} / \mathrm{mL}$ inoculum), was calculated as the difference between the amount of $\mathrm{N}$ added at $t=0$ divided by the volume of inoculum $\left(\mathrm{S}_{0}, \mathrm{mg}\right.$ of $\mathrm{N} / \mathrm{mL}$ inoculum $)$ and the extent of protein degradation $\left(\mathrm{S}_{\mathrm{D}}\right.$, defined above), computed using either TAA assay and ammonia analysis:

$$
\mathrm{S}_{t}=\mathrm{S}_{0}-\mathrm{S}_{\mathrm{D}}
$$

These data were used to estimate fractional degradation rate $\left(\mathrm{k}_{\mathrm{d}}\right)$ as the tangent through the origin of the velocity $(\mathrm{v})$ versus substrate concentration $\left(\left[\mathrm{S}_{0}\right]\right)$ curve, and computed from the ratio of maximum velocity $\left(\mathbf{V}_{\max }\right)$ to Michaelis constant $\left(\mathbf{K}_{\mathrm{m}}\right)$ (i.e., $\mathrm{k}_{\mathrm{d}}=\mathrm{V}_{\max } / \mathrm{K}_{\mathrm{m}}$; Mahler and Cordes, 1966). This was assumed a "blended" or composite ruminal degradation rate contributed by all protein fractions within the sample. This rate was determined using the integrated Michaelis-Menten model (Segal, 1976) as described earlier (Broderick and Clayton, 1992; Colombini et al., 2011):

$$
\mathrm{S}_{t}=\mathrm{S}_{0}-t \times \theta \times \mathrm{K}_{\mathrm{m}}+\mathrm{K}_{\mathrm{m}} \times \ln \left(\mathrm{S}_{0} / \mathrm{S}_{t}\right),
$$

where $\mathrm{S}_{0}$ and $\mathrm{S}_{t}(\mathrm{mg}$ of $\mathrm{N} / \mathrm{mL}$ inoculum) are as defined above, $t(\mathrm{~h})$ is the duration of incubation $(2 \mathrm{~h})$, and $\mathrm{K}_{\mathrm{m}}$ ( $\mathrm{mg}$ of $\mathrm{N} / \mathrm{mL}$ of inoculum) is the Michaelis constant defined as that concentration of substrate that gives "half-maximal velocity." The parameters $\mathrm{K}_{\mathrm{m}}$ and $\theta$ were estimated by nonlinear regression (SAS, 2013). The $\theta$ values were corrected for $\mathrm{FD}_{0}$ (fraction of total 
$\mathrm{N}$ already degraded at $t=0)$ to estimate degradation rate, $\mathrm{k}_{\mathrm{d}}$, as follows:

$$
\mathrm{k}_{\mathrm{d}}=\theta-\mathrm{FD}_{0} / t
$$

where $t=2 \mathrm{~h}$. The proportion RUP was computed using the model of Waldo et al. (1972) applying the blended rate philosophy and different rates of passage for the insoluble $\left(\mathrm{k}_{\mathrm{pi}}\right)$ and soluble $\left(\mathrm{k}_{\mathrm{ps}}\right) \mathrm{N}$ fractions (Colombini et al., 2011):

$$
\begin{gathered}
\text { RUP }=\text { Insoluble } \mathrm{N} \times \mathrm{k}_{\mathrm{pi}} /\left(\mathrm{k}_{\mathrm{pi}}+\mathrm{k}_{\mathrm{d}}\right) \\
+ \text { Soluble } \operatorname{PrN} \times \mathrm{k}_{\mathrm{ps}} /\left(\mathrm{k}_{\mathrm{ps}}+\mathrm{k}_{\mathrm{d}}\right), \\
\mathrm{RDP}=100-\mathrm{RUP},
\end{gathered}
$$

where $\mathrm{k}_{\mathrm{pi}}$ was set equal to $0.06 / \mathrm{h}, \mathrm{k}_{\mathrm{ps}}$ was set equal to $0.16 / \mathrm{h}$, and soluble $\operatorname{PrN}=$ soluble $\mathrm{N}-\mathrm{FD}_{0}$. As discussed previously, the $\mathrm{OPA}_{\mathrm{A}}$ (with correction for $\mathrm{A}_{340}$ without OPA reagent) and $\mathrm{OPA}_{\mathrm{F}}$ assays yielded $\mathrm{FD}_{0}$ estimates that were not different. Using either approach to determine $\mathrm{FD}_{0}$ gave soluble PrN estimates that were not different $(P=0.94)$. Values of soluble $\mathrm{PrN}$ determined using the $\mathrm{OPA}_{\mathrm{F}}$ assay were applied in all RUP estimates.

\section{Statistical Analysis}

Statistical analysis was carried out using the mixed procedures of SAS (2013). The following model was used to assess effects of assaying $\mathrm{FD}_{0}$, soluble $\operatorname{PrN}$, $\mathrm{k}_{\mathrm{d}}$, and $\mathrm{k}_{\mathrm{d}}$ adjusted to the overall mean $\mathrm{k}_{\mathrm{d}}$, using either the $\mathrm{OPA}_{\mathrm{F}}$ or $\mathrm{OPA}_{\mathrm{A}}$ assay (corrected for $\mathrm{A}_{340}$ determined without OPA reagent):

$$
\begin{aligned}
Y_{i j k l}= & \mu+Y_{i}+\mathrm{P}_{j}+M_{k}+Y \times \mathrm{P}_{i j}+Y \times M_{i k} \\
& +\mathrm{P} \times M_{j k}+\operatorname{Rep}_{l}+E_{i j k l},
\end{aligned}
$$

where $Y_{i j k l}=$ dependent variable, $\mu=$ overall mean, $Y_{i}$ $=$ effect of year $i(i=1$ to 4$), \mathrm{P}_{j}=$ effect of plant $j(j$ $=1$ to 12$), M_{k}=$ effect of method $k(k=1$ to 2 , corrected $\mathrm{OPA}_{\mathrm{A}}$ or $\left.\mathrm{OPA}_{\mathrm{F}}\right), Y \times \mathrm{P}_{i j}=$ interaction of year and plant, $Y \times M_{i k}=$ interaction of year and method, $\mathrm{P} \times M_{j k}=$ interaction of plant and method, $\operatorname{Rep}_{l}(l=1$ to 3 replicates per plant per year), and $E_{i j k l}=$ residual error. All terms were considered fixed, except for $\operatorname{Rep}_{l}$ and $E_{i j k l}$, which were considered random. The following overall model was used to fit all composition and ruminal degradation data:

$$
Y_{i j k}=\mu+Y_{i}+\mathrm{P}_{j}+Y \times \mathrm{P}_{i j}+\operatorname{Rep}_{k}+\operatorname{Run}_{l}+E_{i j k l},
$$

where $Y_{i j k}=$ dependent variable, $\mu=$ overall mean, $Y_{i}$ $=$ effect of year $i(i=1$ to 4$), \mathrm{P}_{j}=$ effect of plant $j(j$ $=1$ to 12$), Y \times \mathrm{P}_{i j}=$ interaction of year and plant, $\operatorname{Rep}_{k}=$ effect of sample replicate $(k=1$ to 3 replicates per plant per year), $\operatorname{Run}_{l}=$ effect of in vitro incubation run ( $l=1$ to 3 for 2011, 2012, and 2013, and $l=$ 6 for 2014), and $E_{i j k l}=$ residual error. All terms were considered fixed, except for $\operatorname{Rep}_{k}, \operatorname{Run}_{l}$, and $E_{i j k l}$, which were considered random. Essentially the same model was used to fit data obtained when CM samples from 2013 and 2014 were incubated in the same in vitro runs except that $Y_{i}=$ effect of year $(i=1$ to 2$)$. Sources of variation from sample replicate, in vitro run, year, plant, plus interaction of year and plant were estimated by apportioning total type-3 sums of squares to each source of variation obtained using a SAS GLM version of the overall model. Least squares means estimates are reported; separation of least squares means was conducted at $\alpha=0.05$ using the PDIFF option in the LSMEANS statement. For all statistical analyses, significance was declared at $P \leq 0.05$ and trends at $P \leq$ 0.10 . Simple linear regressions were used to assess relationships between variables shown in Figures 1 and 2 .

\section{RESULTS AND DISCUSSION}

\section{Canola Meal Composition}

Mean composition data of the CM manufactured over the $4 \mathrm{yr}$ are in Table 1. Significant effects of year of sample collection were detected for most of chemical traits analyzed in this study. Some composition differences, such as DM, organic matter, total N, ADF, insoluble and soluble $\mathrm{N}$, and soluble protein-N, were relatively small but were either significant or highly significant based on year of collection. A surprisingly large difference among years was detected for NDF content, which ranged from about $26 \%$ (2011) to almost $31 \%$ (2013). However, the overall NDF mean of $28.6 \%$ may be compared with the value of $29.8 \%$ reported in NRC (2001) tables for "mechanically expelled" CM. Concentrations of most of the macronutrients were also similar to those tabulated by NRC (2001), with CP being the notable exception; the overall mean $6.65 \% \mathrm{~N}$ is equivalent to $41.6 \%$ versus $37.8 \% \mathrm{CP}$ in NRC (2001) tables. Solvent-extracted CM was reported to contain a mean $40.9 \%$ CP (Newkirk, 2009). No year effect on NDIN content in CM (expressed as \% of total N) was observed and, despite differences in ADIN content, $\mathrm{N}$-fraction $\mathrm{B}_{3}(\mathrm{NDIN}-\mathrm{ADIN})$ did not differ among years.

Concentrations of TAA/N, which were determined by acid hydrolysis, were also different based on the year of sample collection (Table 1). The $\mathrm{OPA}_{\mathrm{F}}$ and $\mathrm{OPA}_{\mathrm{A}}$ 


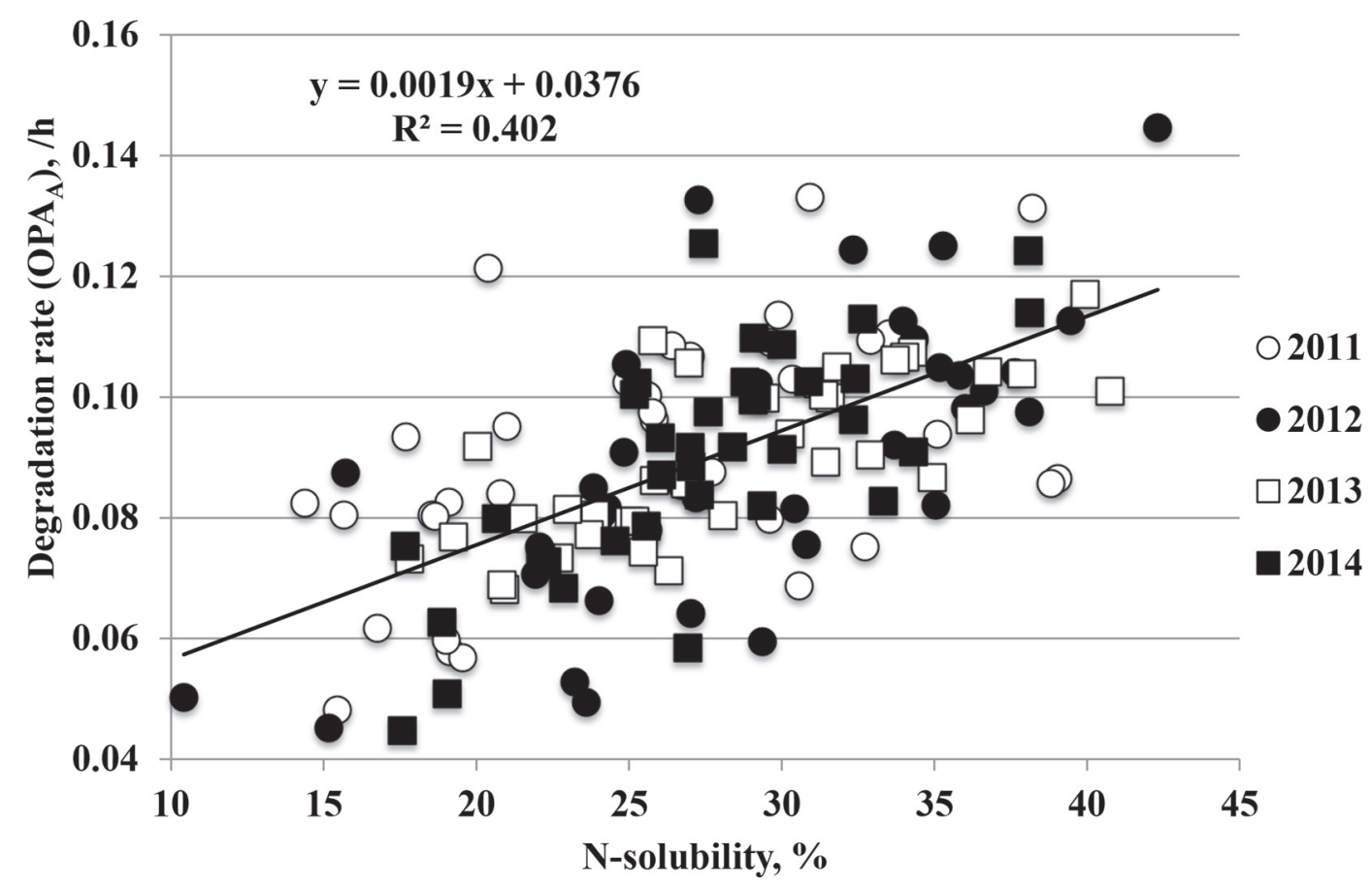

Figure 1. Regression of ruminal in vitro degradation rate, estimated using o-phthaldialdehyde absorbance $\left(\mathrm{OPA}_{\mathrm{A}}\right)$ methodology, on buffer N-solubility of canola meals collected over 4 yr from 12 production plants.

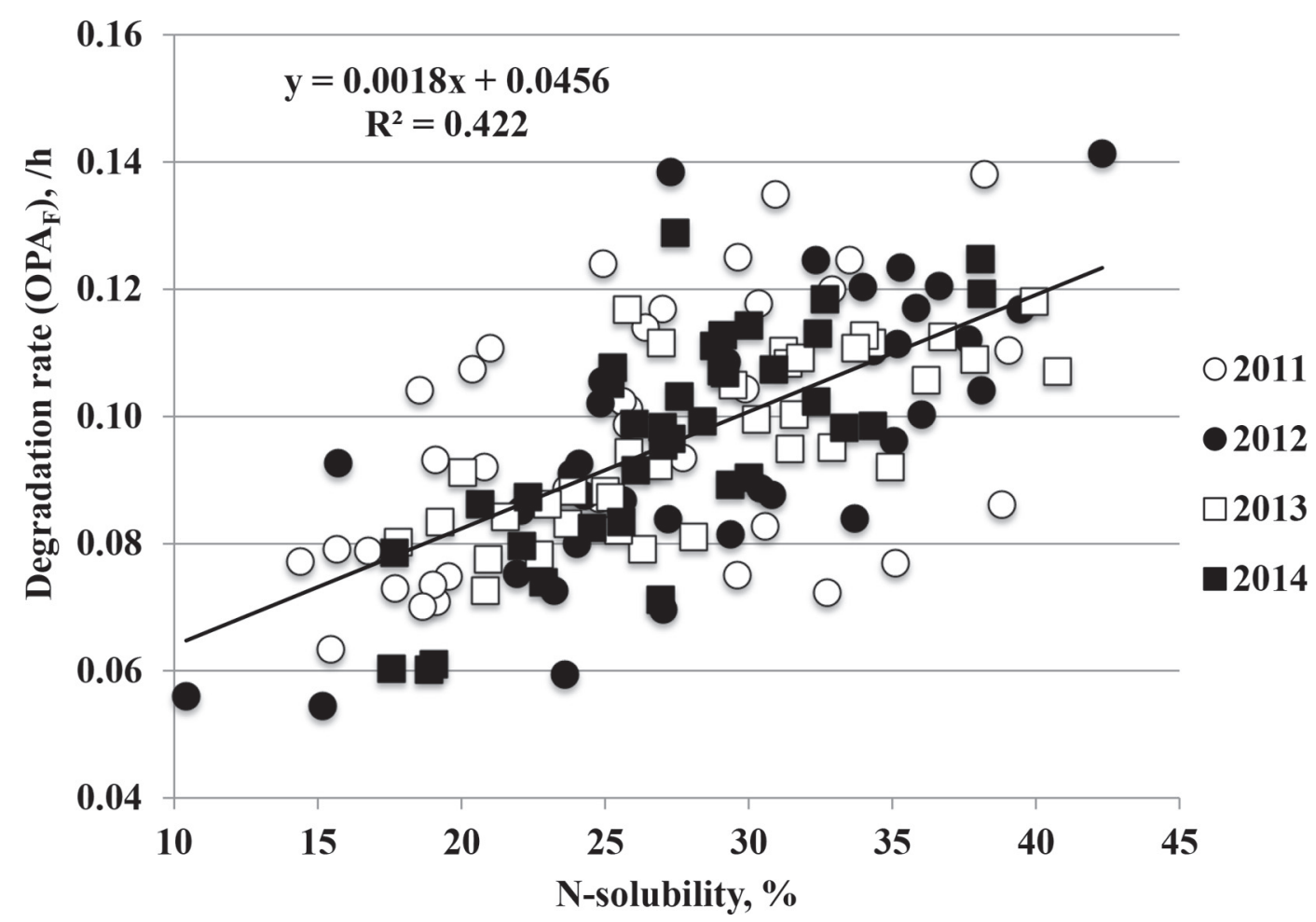

Figure 2. Regression of ruminal in vitro degradation rate, estimated using o-phthaldialdehyde fluorescence $\left(\mathrm{OPA}_{\mathrm{F}}\right)$ methodology, on buffer N-solubility of canola meals collected over 4 yr from 12 production plants. 
values are critical because they are used in the assay to compute the amount of degraded protein from net release of TAA and TAA plus oligopeptides, respectively. Protein AA composition is of course dictated by the cell's DNA template; it seems likely that these apparent differences among years resulted from small "methodological" shifts, such as new standards and standard curves being used over time to compute TAA concentration. However, any effect of changing standard curves would have the same effects on TAA and oligopeptide concentrations determined in the in vitro incubations. Moreover, it was noted that $\mathrm{OPA}_{\mathrm{F}}$ and $\mathrm{OPA}_{\mathrm{A}}$ values did not differ among processing plant $(P$ $=0.73$ and 0.74 ), which allowed mean $\mathrm{TAA} / \mathrm{N}$ ratios to be applied to all data from all plants within a year. Fraction degraded at $t=0\left(\mathrm{FD}_{0}\right)$ is also important in computing degradation rate. Although an apparent year effect was detected when samples were analyzed by year, when all $144 \mathrm{CM}$ samples were reanalyzed at one time (with the same AA standard curve), no effect of collection year was found $(P=0.36)$.

Mean composition data of the CM manufactured by the 12 crushing plants over the 4 sampling years are in Table 2. Eleven of the 12 crushing plants applied prepress solvent extraction to remove oil; plant 12 was the only facility using the expeller process for oil removal. Expeller processing would be expected to generate more heat and remove less oil, effects that were reflected in meal composition: CM from plant 12 had the highest DM; second highest NDIN, N-fraction
$\mathrm{B}_{3}$, and insoluble $\mathrm{N}$; numerically highest ADIN; and lowest $\mathrm{N}$ concentration. Except for ADIN content and the $\mathrm{OPA}_{\mathrm{F}}$ and $\mathrm{OPA}_{\mathrm{A}}$ values mentioned earlier, significant or highly significant differences existed among plants for all chemical factors measured in this study. This outcome was probably partly due to the statistical power resulting from the high degree of replication among the processing plants over the 4 sampling years. Of particular interest were the differences in NDIN, N-fraction $\mathrm{B}_{3}$, and insoluble $\mathrm{N}$, even among $\mathrm{CM}$ from plants applying prepress solvent extraction. The relationship of these 3 factors to protein degradation rate and RUP content are discussed in the next section. It was also noted that the 12 crushing plants, although anonymous, were located in 5 Canadian provinces (Quebec, Ontario, Manitoba, Saskatchewan, and Alberta). Thus, the canola seed processed by each plant originated from various canola cultivars grown over widely varying geographical areas with a range of soil types and environmental conditions. Mean temperature and moisture had greater effects than cultivar on oil and protein content of canola seed grown in Australia from 1985 through 1994 (Pritchard et al., 2000). Canola cultivar had greater effects on fatty acid composition and spring temperatures and moisture had greater effects on oil and protein content of canola seed grown in Canadian trials (McCartney et al., 2004). Timing and amount of $\mathrm{N}$ fertilization interacted with soil type to influence composition and yield of canola seed (Brennan, 2016).

Table 1. Mean chemical composition of canola meals from all 4 yr

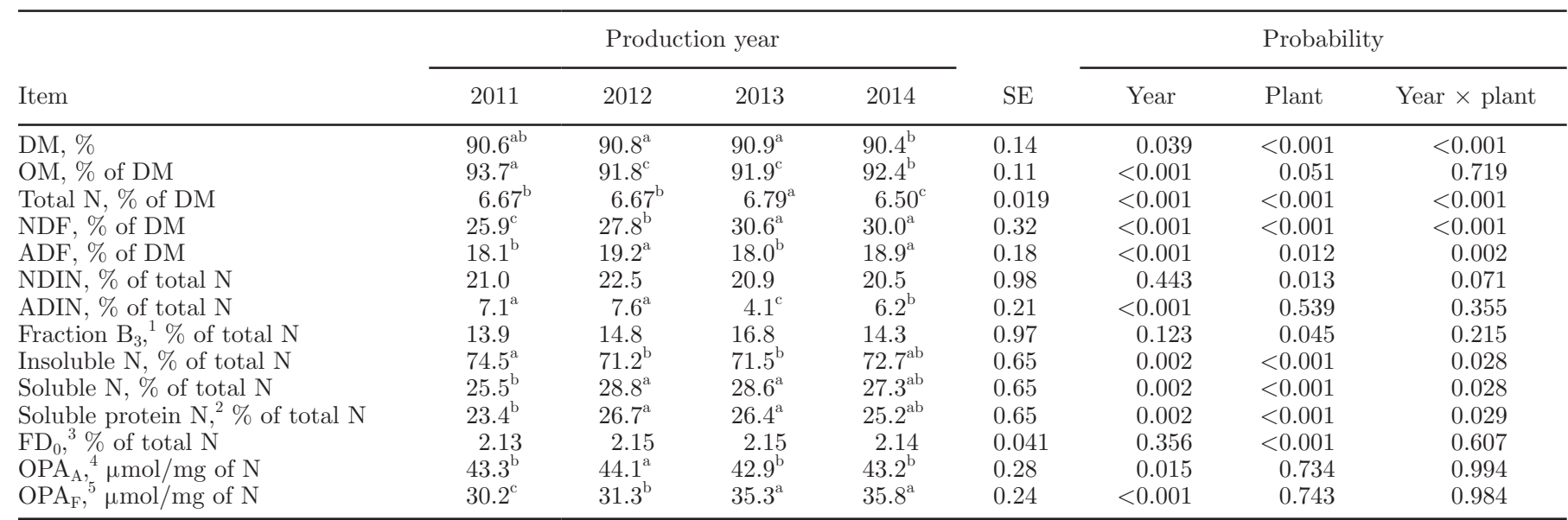

${ }^{\mathrm{a}-\mathrm{c}} \mathrm{LSM}$ with different superscript letters among years are different $(P<0.05)$.

${ }^{1}$ Fraction $\mathrm{B}_{3}=$ NDIN - ADIN.

${ }^{2}$ Soluble protein $\mathrm{N}=$ Soluble $\mathrm{N}-\mathrm{FD}_{0}$.

${ }^{3} \mathrm{FD}_{0}=$ fraction total $\mathrm{N}$ present as degraded $\mathrm{N}$ (ammonia + free $\mathrm{AA}$ ) at $t=0$.

${ }^{4} \mathrm{OPA}$ (o-phthalaldehyde) color factor $\left(\mathrm{A}_{340}\right)$ in $\mu \mathrm{mol}$ of Leu equivalents $/ \mathrm{mg}$ of $\mathrm{N}$.

${ }^{5}$ OPA fluorescence factor in $\mu \mathrm{mol}$ of Leu equivalents/mg of $\mathrm{N}$. 
CHEMICAL AND RUMEN PROPERTIES OF CANOLA MEAL

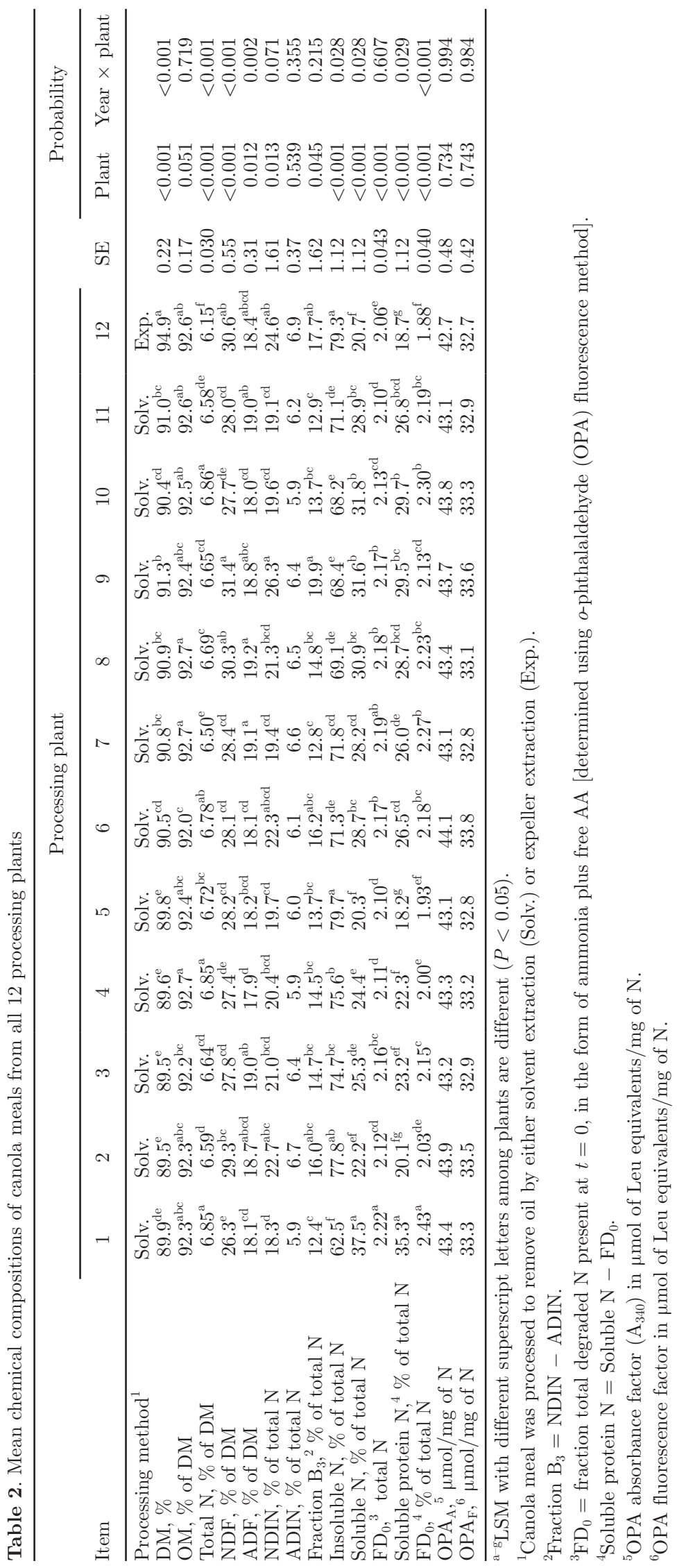




\section{Determination of Ruminal Protein Degradability}

Degradation data obtained for the standard proteins casein, SSBM, and ESBM in the MMIIV system are in Table 3. Michaelis constant $\left(\mathrm{K}_{\mathrm{m}}\right)$ and maximum velocity $\left(\mathrm{V}_{\max }\right)$ are reported in addition to degradation rate and proportions of RUP and RDP. Values of $\mathrm{K}_{\mathrm{m}}$ represent affinity of the substrate for the enzyme system (Mahler and Cordes, 1966) and are inversely related to reaction rate. The maximal rate of an enzymatic process is represented by $\mathrm{V}_{\max }$ (Segal, 1976), which should be similar for all substrates tested; $V_{\max }$ was not different among the 3 standard proteins, indicating that the MMIIV system met this general requirement. As expected, detection of oligopeptides in addition to TAA yielded higher $\mathrm{k}_{\mathrm{d}}$ and lower RUP estimates for the $\mathrm{OPA}_{\mathrm{A}}$ method versus the $\mathrm{OPA}_{\mathrm{F}}$ method. This outcome was observed previously for these same proteins (Colombini et al., 2011). Ruminal metabolism of small peptides is very dynamic (Chen et al., 1987; Broderick et al., 1988), and peptides contribute small but significant amounts to the total AA flow from the rumen (Choi et al., 2003). When tested earlier, the standard proteins yielded somewhat different degradation rates and RUP values (Colombini et al., 2011): RUP estimates made using $\mathrm{OPA}_{\mathrm{F}}$ and $\mathrm{OPA}_{\mathrm{A}}$ methodology were, respectively, 21 and $27 \%$ (casein), 35 and $38 \%$ (SSBM), and 42 and $48 \%$ (ESBM). Values of 31 and $35 \%$ RUP were observed for SSBM in the present study; however, 54 and 59\% RUP were obtained for ESBM. The difference between trials for ESBM was partly due to greater N-solubility in the current study (8.5\%) versus the lower earlier measurement on the same protein (4.5\%). Applying the same blended rate to proteins of greater solubility results in a greater RUP estimate because of the higher passage rate from the rumen. One may speculate that the ideal high RUP protein would be both resistant to ruminal degradation but soluble and thus passing rapidly with the liquid phase. Degradation rates and RUP values (at DMI $=4 \%$ of BW) for SSBM and ESBM assigned in NRC (2001) tables are, respectively, 0.075 and $0.024 / \mathrm{h}$ and 43 and $69 \%$. Although based on very different in situ methods, the SSBM/ESBM ratios for the NRC (2001) are 3.1 (degradation rate) and 0.6 (RUP), similar to the values observed for these ratios in the present study. These results indicated that the MMIIV system yielded reliable relative estimates of protein degradation rate and RUP values for the standard proteins and would thus be expected to yield reliable protein degradability data for the CM sample set. Although $\theta$ and thus $\mathrm{k}_{\mathrm{d}}$ were similar among years, RUP values estimated by both the $\mathrm{OPA}_{\mathrm{A}}$ and $\mathrm{OPA}_{\mathrm{F}}$ assays differed by incubation year (Table 3). This outcome likely results from applying constant proportions of soluble and insoluble protein for each standard protein plus constant passage rates; this approach yields RUP values with lower variation than is obtained for $k_{d}$.

In addition to $\mathrm{N}$ composition data, mean ruminal protein degradation results for the CM manufactured over the 4 sampling years are in Table 4 . Large differences existed among years in $\theta$; this result indicated that large differences were present in degradation rate $\mathrm{k}_{\mathrm{d}}$, which is computed by discounting $\theta$ for $\mathrm{FD}_{0}$ (fraction of total $\mathrm{N}$ already degraded at $t=0$ ). Lowest mean $\theta$ was observed in 2012, when the SRF had to be transported about $40 \mathrm{~km}$ for 50 min before pre-incubation. However, a year effect was not observed for $\theta$ and $k_{d}$ determined for the 3 standard proteins (Table 3). Earlier, substantial day-to-day differences in degradation rate also were observed for the same proteins incubated with ruminal inocula prepared from SRF within $5 \mathrm{~min}$ of collection from the same donor cows and fed the same diets (Broderick et al., 2004). Therefore, we decided to directly test the effect of year by rerunning CM collected in 2013 in the same incubations as CM collected in 2014 to assess whether CM protein degradability varied because of production year; these data are in Table 5. As shown in Table 1, $\mathrm{N}$ composition also differed for CM from 2013 and 2014. However, no differences existed between years $(P \geq 0.36)$ for $\theta$, $\mathrm{k}_{\mathrm{d}}$, RUP, and RDP. Thus, apparent differences among years for the degradation parameters shown in Table 4 reflected the high variability in degradative activity among ruminal inocula. We decided to adjust $\theta$ observed for each protein within each incubation, by dividing the observed $\theta$ by the ratio: mean incubation $\theta$ /overall 4-year mean $\theta$. The adjusted $\theta$ values, plus the $\mathrm{k}_{\mathrm{d}}$, RUP, and RDP computed from these values, are reported in Table 4 and again show no differences in CM degradability among years of sample collection. Mean $\mathrm{k}_{\mathrm{d}}$ and RUP values for CM for both assays over all $4 \mathrm{yr}$ were $0.09 / \mathrm{h}$ and $45 \%$, compared with $\mathrm{k}_{\mathrm{d}}$ and RUP of $0.16 / \mathrm{h}$ and $33 \%$ for SSBM and $0.05 / \mathrm{h}$ and $56 \%$ for ESBM. Maxin et al. (2013a) reported in situ $\mathrm{k}_{\mathrm{d}}$ and RUP for CM of $0.06 / \mathrm{h}$ and $53 \%$ versus $\mathrm{k}_{\mathrm{d}}$ and RUP of $0.09 / \mathrm{h}$ and $42 \%$ for SSBM. Note that, unlike in the in situ method, soluble protein contributes to the measured degradation rate and RUP in the MMIIV system.

Mean ruminal protein degradation results using adjusted $\theta$ values for $\mathrm{CM}$ produced by the 12 canola crushing plants over all 4 sampling years are in Table 6 . These results were highly significantly different among plants. Note that for both $\mathrm{OPA}_{\mathrm{A}}$ and $\mathrm{OPA}_{\mathrm{F}}$ data the magnitude of $\theta$ and adjusted $\theta$ values are almost identical. However, the spread of mean separations was somewhat narrower after adjustment: $\theta$ mean separations were a to g, but adjusted $\theta$ mean separations were a to $f$ 
$\left(\mathrm{OPA}_{\mathrm{A}}\right) ; \theta$ mean separations were a to $\mathrm{f}$, but adjusted $\theta$ mean separations were a to $\mathrm{d}\left(\mathrm{OPA}_{\mathrm{F}}\right)$. What was striking was the wide differences in degradability among CM produced by the 12 plants that were consistent between the 2 methods: $\mathrm{k}_{\mathrm{d}}$ ranged from 0.069 to $0.113 / \mathrm{h}$ and RUP from 51 to $43 \%\left(\mathrm{OPA}_{\mathrm{A}}\right)$, and $\mathrm{k}_{\mathrm{d}}$ ranged from 0.075 to $0.120 / \mathrm{h}$ and RUP from 49 to $41 \%\left(\mathrm{OPA}_{\mathrm{F}}\right)$. The CM produced by plants 5 (a prepress solvent extraction plant) and 12 (the sole expeller plant) averaged 7.7 and 7.2 percentage units greater RUP than CM produced by prepress solvent extraction plants 1 and 10, a mean $18 \%$ greater RUP by both methods.

The similarity of CM $\mathrm{k}_{\mathrm{d}}$ and RUP values determined by the $\mathrm{OPA}_{\mathrm{A}}$ and $\mathrm{OPA}_{\mathrm{F}}$ methods was surprising and unexpected. Research with casein, ESBM, and SSBM conducted previously (Colombini et al., 2011) indicated more rapid $\mathrm{k}_{\mathrm{d}}$ and lower RUP estimates using the $\mathrm{OPA}_{\mathrm{A}}$ assay, reflecting the contribution of oligopeptide release with $\mathrm{OPA}_{\mathrm{A}}$ assay. In the present study, use of the $\mathrm{OPA}_{\mathrm{A}}$ assay yielded $\mathrm{k}_{\mathrm{d}}$ that were $15 \%$ greater for casein and $25 \%$ greater for the 2 SBM, while RUP estimates were reduced an average $11 \%$ across the 3 standard proteins (Table 3). Analysis of CM data before adjustment for run variation yielded mean $\mathrm{k}_{\mathrm{d}}$ of 0.095 and $0.092 / \mathrm{h}$ for, respectively, the $\mathrm{OPA}_{\mathrm{A}}$ and $\mathrm{OPA}_{\mathrm{F}}$ assays $(P=0.039)$; however, this difference disappeared after the adjustment. Computation of $\mathrm{k}_{\mathrm{d}}$ derives in part from dividing net TAA $\left(\mathrm{OPA}_{\mathrm{F}}\right)$ or TAA plus peptide $\left(\mathrm{OPA}_{\mathrm{A}}\right)$ release by the TAA/N constants obtained from $\mathrm{HCl}$ hydrolysis; overall mean TAA/N constants were 43.4 and $33.2 \mu \mathrm{mol} / \mathrm{mg} \mathrm{N}$ for, respectively, the $\mathrm{OPA}_{\mathrm{A}}$ and $\mathrm{OPA}_{\mathrm{F}}$ assays (Table 1 ). These results suggest that peptide accumulation makes a smaller contribution to the degradation rates estimated for CM protein versus the proteins in casein and SBM. Substantial differences in rates of disappearance of various di- and tripeptides have been observed (Broderick et al., 1988); it may be that AA composition of the peptides released during ruminal CM degradation are such that they are rapidly catabolized by ruminal microorganisms.

Clearly, consistent differences existed among processing plants in the CM that they produced. Assuming intestinal digestibility was not impaired, RUP differences of the magnitudes estimated by the MMIIV procedure imply that MP and AA supply could differ substantially among CM produced at different plants.

Table 3. Composition and ruminal in vitro degradation results for casein, solvent soybean meal (SSBM), and expeller soybean meal (ESBM) included in the incubations

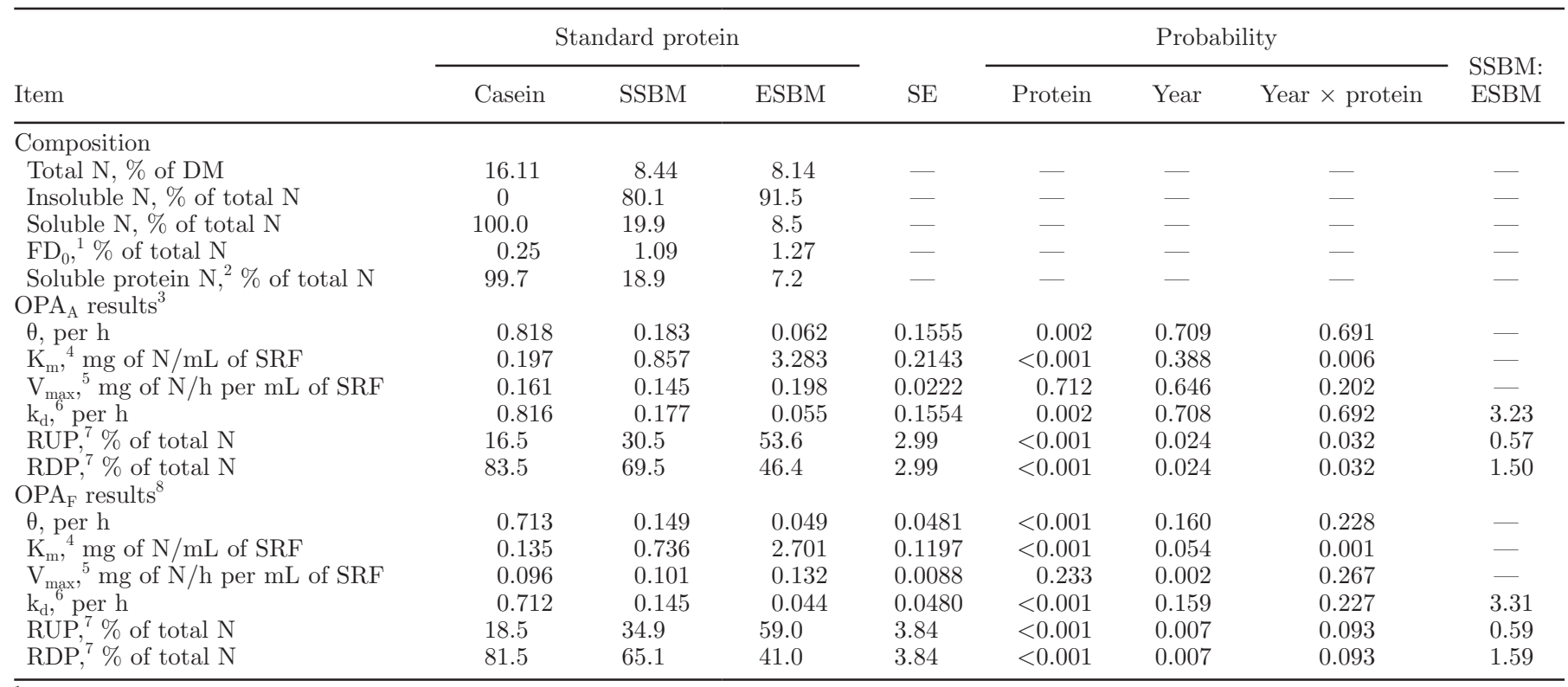

${ }^{1} \mathrm{FD}_{0}=$ fraction total $\mathrm{N}$ present as degraded $\mathrm{N}$ (ammonia and free $\mathrm{AA}$ ) at $t=0$. Values in this table are $\mathrm{FD}_{0}$ means determined using $\mathrm{OPA}_{\mathrm{F}}$ and $\mathrm{OPA}_{\mathrm{A}}$ methodology.

${ }^{2}$ Soluble protein $\mathrm{N}=$ Soluble $\mathrm{N}-\mathrm{FD}_{0}$.

${ }^{3}$ Degradation determined from net release of ammonia plus o-phthalaldehyde (OPA) absorbance $\left(\mathrm{A}_{340}\right)$, which includes free AA plus oligopeptides.

${ }^{4}$ Michaelis constant per $\mathrm{mL}$ of strained ruminal fluid (SRF) in inoculum.

${ }^{5}$ Maximum velocity per $\mathrm{mL}$ of strained ruminal fluid (SRF) in inoculum.

${ }^{6}$ Degradation rate $\left(\mathrm{k}_{\mathrm{d}}\right)=\theta-\left(\mathrm{FD}_{0} / 100\right) /$ incubation time $(2 \mathrm{~h})$.

${ }^{7} \mathrm{RUP}=$ insoluble $\mathrm{N} \times 0.06 /\left(0.06+\mathrm{k}_{\mathrm{d}}\right)+$ soluble protein $\mathrm{N} \times 0.16 /\left(0.16+\mathrm{k}_{\mathrm{d}}\right) ; \mathrm{RDP}=100-\mathrm{RUP}$.

${ }^{8}$ Degradation determined from net release of ammonia plus OPA fluorescence, which includes only free AA. 
Newkirk et al. (2003) found significant differences in digestibility in broiler chickens of $\mathrm{CP}$ and 16 AA due to plant of origin for $31 \mathrm{CM}$ samples obtained from 7 crushing plants, all of which applied prepress solvent extraction; effects were greatest for Lys, the digestibility of which ranged from 70.4 to $82.1 \%$ among CM from the 7 plants. The authors attributed this effect to the Maillard reaction during toasting, which is used to remove hexane (Classen et al., 2004); these findings were later confirmed in swine (Thacker and Newkirk, 2005). The differences we observed in ruminal protein degradation in CM produced by the various crushing plants could be explained by differences in degree of heating when meal is desolventized (Moshtaghi Nia and Ingalls, 1995). Heat-treating protein concentrates to improve RUP requires finding the optimum balance between ruminal protein escape and intestinal protein digestion (e.g., Faldet et al., 1992). Huhtanen et al. (2011) observed numerically greater milk yield response to heat-treated $\mathrm{CM}$ versus conventional $\mathrm{CM}$, although this difference was not significant $(P=0.30)$. We suggest that application of consistent temperature treatments during prepress solvent processing among canola crushing plants would result in production of
CM with more uniform RUP content and nutritional value.

Assessing plant $\times$ year interactions was not an original objective and was considered beyond the scope of this research; however, this interaction proved to be highly significant for several composition and ruminal degradation traits in this data set (Table 6). This finding may have partly resulted from the strong statistical power of this study referred to earlier. We estimated the relative contributions to total variance by apportioning GLM type-3 sums of squares for the different model components (Table 7). The statistical models explained an estimated 41 to $83 \%$ of observed variation. Except for the fraction degraded at $t=0$ (for both $\mathrm{FD}_{0 \mathrm{~A}}$ and $\mathrm{FD}_{0 \mathrm{~F}}$ ), sample replicate contributed little to overall variance. Incubation run and year were also unimportant except for unadjusted $\theta$. Averaging $\mathrm{OPA}_{\mathrm{A}}$ and $\mathrm{OPA}_{\mathrm{F}}$ data, plant accounted for $35 \%\left(\mathrm{k}_{\mathrm{d}}\right)$ and $23 \%$ (RUP) of total variance, and plant $\times$ year accounted for $15 \%\left(\mathrm{k}_{\mathrm{d}}\right)$ and $18 \%$ (RUP) of total variance, suggesting that plant was substantially more important as a factor determining rate of CM protein degradation.

We used simple regressions of degradation rate $\mathrm{k}_{\mathrm{d}}$, determined by both $\mathrm{OPA}_{\mathrm{A}}$ and $\mathrm{OPA}_{\mathrm{F}}$ methodology, on

Table 4. Mean yearly ruminal in vitro degradation results for canola meals collected over 4 production years

\begin{tabular}{|c|c|c|c|c|c|c|c|}
\hline \multirow[b]{2}{*}{ Item } & \multicolumn{4}{|c|}{ Production year } & \multirow[b]{2}{*}{$\mathrm{SE}$} & \multicolumn{2}{|c|}{ Probability } \\
\hline & 2011 & 2012 & 2013 & 2014 & & Year & Year $\times$ plant \\
\hline \multicolumn{8}{|c|}{ Composition, $\%$ of total $\mathrm{N}$} \\
\hline Insoluble N & $74.5^{\mathrm{a}}$ & $71.2^{\mathrm{b}}$ & $71.5^{\mathrm{b}}$ & $72.7^{\mathrm{ab}}$ & 0.65 & 0.002 & 0.028 \\
\hline Soluble N & $25.5^{\mathrm{b}}$ & $28.8^{\mathrm{a}}$ & $28.6^{\mathrm{a}}$ & $27.3^{\mathrm{ab}}$ & 0.65 & 0.002 & 0.028 \\
\hline $\mathrm{FD}_{0}^{1}$ & 2.13 & 2.15 & 2.15 & 2.14 & 0.041 & 0.356 & 0.607 \\
\hline Soluble protein $\mathrm{N}^{2}$ & $23.1^{\mathrm{c}}$ & $27.1^{\mathrm{a}}$ & $26.3^{\mathrm{ab}}$ & $25.2^{\mathrm{b}}$ & 0.65 & $<0.001$ & 0.034 \\
\hline \multicolumn{8}{|l|}{$\mathrm{OPA}_{\mathrm{A}}$ results $^{3}$} \\
\hline $\mathrm{FD}_{0 \mathrm{~A}}, 4 \%$ of total $\mathrm{N}$ & $7.07^{\mathrm{b}}$ & $7.20^{\mathrm{a}}$ & $7.02^{\mathrm{b}}$ & $7.18^{\mathrm{a}}$ & 0.105 & $<0.001$ & 0.003 \\
\hline$\theta$, per $\mathrm{h}$ & $0.113^{\mathrm{c}}$ & $0.094^{\mathrm{d}}$ & $0.142^{\mathrm{b}}$ & $0.149^{\mathrm{a}}$ & 0.003 & $<0.001$ & $<0.001$ \\
\hline Adjusted $\theta,{ }^{5}$ per $\mathrm{h}$ & 0.125 & 0.125 & 0.125 & 0.125 & 0.0018 & 0.997 & $<0.001$ \\
\hline $\mathrm{k}_{\mathrm{d}},{ }^{\circ}$ per $\mathrm{h}$ & 0.090 & 0.089 & 0.090 & 0.090 & 0.0018 & 0.954 & $<0.001$ \\
\hline RUP ${ }^{7} \%$ of total $\mathrm{N}$ & 46.0 & 47.1 & 45.8 & 46.1 & 0.49 & 0.199 & $<0.001$ \\
\hline $\mathrm{RDP}^{7} \%$ of total $\mathrm{N}$ & 54.0 & 52.9 & 54.2 & 53.9 & 0.49 & 0.199 & $<0.001$ \\
\hline \multicolumn{8}{|l|}{$\mathrm{OPA}_{\mathrm{F}}$ results 8} \\
\hline $\mathrm{FD}_{0 \mathrm{~F}},{ }^{9} \%$ of total $\mathrm{N}$ & 2.13 & 2.15 & 2.15 & 2.14 & 0.041 & 0.356 & 0.607 \\
\hline$\theta$, per $\mathrm{h}$ & $0.100^{\mathrm{c}}$ & $0.078^{\mathrm{d}}$ & $0.122^{\mathrm{b}}$ & $0.127^{\mathrm{a}}$ & 0.0029 & $<0.001$ & $<0.001$ \\
\hline Adjusted $\theta,^{5}$ per $\mathrm{h}$ & 0.107 & 0.107 & 0.107 & 0.107 & 0.0017 & 1.000 & $<0.001$ \\
\hline $\mathrm{k}_{\mathrm{d}},{ }^{6}$ per $\mathrm{h}$ & 0.094 & 0.098 & 0.095 & 0.096 & 0.0017 & 0.382 & $<0.001$ \\
\hline $\mathrm{RUP}^{7} \%$ of total $\mathrm{N}$ & 44.4 & 44.7 & 44.3 & 44.1 & 0.41 & 0.738 & $<0.001$ \\
\hline $\mathrm{RDP}^{7} \%$ of total $\mathrm{N}$ & 55.6 & 55.3 & 55.7 & 55.9 & 0.41 & 0.738 & $<0.001$ \\
\hline
\end{tabular}

${ }^{\mathrm{a}-\mathrm{d}} \mathrm{LSM}$ with different superscript letters among years are different $(P<0.05)$.

${ }^{1} \mathrm{FD}_{0}=$ fraction total $\mathrm{N}$ present as degraded $\mathrm{N}$ [ammonia and free $\mathrm{AA}$ (OPA fluorescence)] at $t=0$, where OPA $=o$-phthalaldehyde.

${ }^{2}$ Soluble protein $\mathrm{N}=$ Soluble $\mathrm{N}-\mathrm{FD}_{0}$.

${ }^{3}$ Degradation determined from net release of ammonia plus OPA absorbance $\left(\mathrm{A}_{340}\right)$, which includes free AA plus oligopeptides.

${ }^{4} \mathrm{FD}_{0 \mathrm{~A}}=$ fraction total $\mathrm{N}$ present as degraded $\mathrm{N}$ [ammonia and free AA plus oligopeptides $\left(\mathrm{A}_{340}\right)$ ] at $t=0$.

${ }^{5}$ Adjusted $\theta$ computed by dividing $\theta$ observed for individual proteins in each incubation by the ratio: mean incubation $\theta$ /overall mean $\theta$.

${ }^{6}$ Degradation rate $\left(\mathrm{k}_{\mathrm{d}}\right)=$ adjusted $\theta-\left(\mathrm{FD}_{0} / 100\right) /$ incubation time $(2 \mathrm{~h})$.

${ }^{7} \mathrm{RUP}=$ insoluble $\mathrm{N} \times 0.06 /\left(0.06+\mathrm{k}_{\mathrm{d}}\right)+$ soluble protein $\mathrm{N} \times 0.16 /\left(0.16+\mathrm{k}_{\mathrm{d}}\right) ; \mathrm{RDP}=100-\mathrm{RUP}$.

${ }^{8}$ Degradation determined from net release of ammonia plus OPA fluorescence, which includes only free AA.

${ }^{9} \mathrm{FD}_{0 \mathrm{~F}}=$ fraction total $\mathrm{N}$ present as degraded $\mathrm{N}$ [ammonia and free AA (OPA fluorescence)] at $t=0$. 
Table 5. Ruminal in vitro degradation results for canola meals collected in 2013 and 2014 and incubated simultaneously in the same incubations

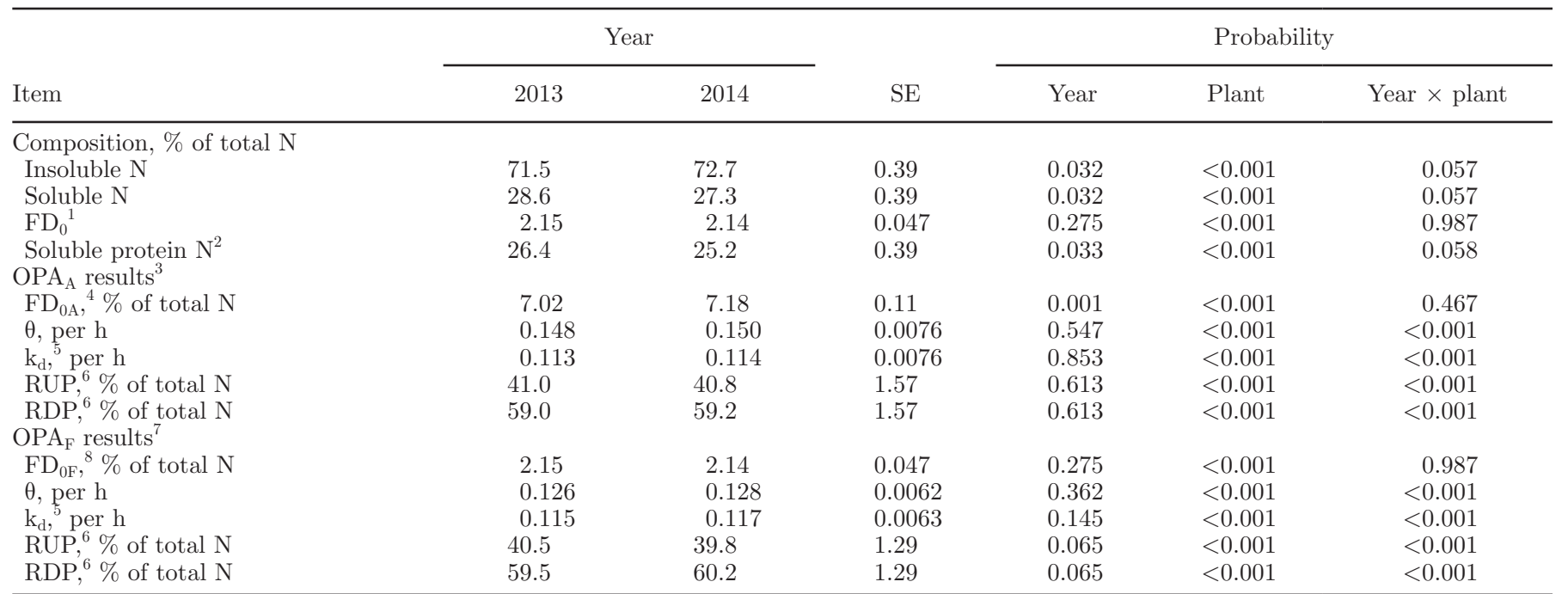

${ }^{1} \mathrm{FD}_{0}=$ fraction total $\mathrm{N}$ present as degraded $\mathrm{N}$ [ammonia and free AA (OPA fluorescence)] at $t=0$, where OPA $=o$-phthalaldehyde.

${ }^{2}$ Soluble protein $\mathrm{N}=$ Soluble $\mathrm{N}-\mathrm{FD}_{0}$.

${ }^{3}$ Degradation determined from net release of ammonia plus OPA absorbance $\left(\mathrm{A}_{340}\right)$, which includes free AA plus oligopeptides.

${ }^{4} \mathrm{FD}_{0 \mathrm{~A}}=$ fraction total $\mathrm{N}$ present as degraded $\mathrm{N}$ [ammonia and free AA plus oligopeptides $\left(\mathrm{A}_{340}\right)$ ] at $t=0$.

${ }^{5}$ Degradation rate $\left(\mathrm{k}_{\mathrm{d}}\right)=\theta-\left(\mathrm{FD}_{0} / 100\right) /$ incubation time $(2 \mathrm{~h})$.

${ }^{6} \mathrm{RUP}=$ insoluble $\mathrm{N} \times 0.06 /\left(0.06+\mathrm{k}_{\mathrm{d}}\right)+$ soluble protein $\mathrm{N} \times 0.16 /\left(0.16+\mathrm{k}_{\mathrm{d}}\right) ; \mathrm{RDP}=100-\mathrm{RUP}$.

${ }^{7}$ Degradation determined from net release of ammonia plus OPA fluorescence, which includes only free AA.

${ }^{8} \mathrm{FD}_{0 \mathrm{~F}}=$ fraction total $\mathrm{N}$ present as degraded $\mathrm{N}$ [ammonia and free AA (OPA fluorescence) $]$ at $t=0$.

soluble $\mathrm{N}$, NDIN, and $\mathrm{N}$-fraction $\mathrm{B}_{3}$ (as proportions of total $\mathrm{N}$ ) to assess their relationships to $\mathrm{CM}$ protein degradability. Regressions on NDIN and fraction $\mathrm{B}_{3}$ yielded correlation coefficients $\left(\mathrm{R}^{2}\right)$ of only 0.021 and 0.015, respectively. However, regressions on soluble $\mathrm{N}$ yielded $\mathrm{R}^{2}$ of 0.402 for $\mathrm{k}_{\mathrm{d}}$ determined by $\mathrm{OPA}_{\mathrm{A}}$ (Figure 1) and 0.422 for $\mathrm{k}_{\mathrm{d}}$ determined by $\mathrm{OPA}_{\mathrm{F}}$ (Figure 2). Of course, regressing $\mathrm{k}_{\mathrm{d}}$ on insoluble $\mathrm{N}$ yielded identical $\mathrm{R}^{2}$ but negative slopes. Although about $60 \%$ of the variation in $\mathrm{k}_{\mathrm{d}}$ was still unexplained, this finding was of interest. Heat treatment reduces protein solubility in cottonseed meal (Craig and Broderick, 1981), soybeans (Faldet and Satter, 1991), SBM (Borucki Castro et al., 2007), CM (Moshtaghi Nia and Ingalls, 1995), and other proteins. Heat treatment of protein also promotes the Maillard reaction between lysine residues and reducing sugars present in feeds that alter susceptibility of proteins to digestion in the rumen (Faldet et al., 1992) and small intestine (Friedman, 1996). Extent of the Maillard reaction is directly related to extent of ruminal protein escape (Boucher et al., 2009), and protein solubility/insolubility could thus be correlated to several factors influencing ruminal protein degradation and escape.

Substantial in vivo evidence exists for differences in lactation performance between dairy cows fed SSBM and ESBM (e.g., Broderick et al., 1990) and between dairy cows fed SSBM and CM (Huhtanen et al., 2011; Martineau et al., 2013). Greater milk and protein yield were observed when equal CP diets containing CM replaced those containing SSBM; lower ruminal concentrations of ammonia and branched-chain VFA suggested that at least part of the positive effect of replacing SSBM was due to greater RUP on the CM diets (Broderick et al., 2015). However, we know of no published in vivo data showing differences in milk or protein yield among CM coming from different processing plants. Using omasal sampling, Brito et al. (2007) found a numeric difference in RUP flow of $90 \mathrm{~g} / \mathrm{d}$ when CM substituted for equal CP from SSBM in cows consuming about $1.6 \mathrm{~kg}$ CP from either supplement. Mean RUP estimated by both $\mathrm{OPA}_{\mathrm{A}}$ and $\mathrm{OPA}_{\mathrm{F}}$ methods was $33 \%$ for SSBM and $45 \%$ over all CM plants from all 4 sampling years; if these RUP values were applied in vivo, then RUP flow should have been about $180 \mathrm{~g} / \mathrm{d}$ greater on $\mathrm{CM}$ than SSBM, a result about twice that observed in the trial of Brito et al. (2007). Maxin et al. (2013b) determined differences in whole-body irreversible loss of Lys, Met, and His (estimates of net AA absorption) in dairy cows fed SBM and CM; Lys irreversible loss was higher and irreversible loss of Met and His was numerically higher on CM versus SBM. Greater contribution of MP from CM than SSBM is consistent with our present in vitro findings and emphasizes the importance of improving 
BRODERICK ET AL.

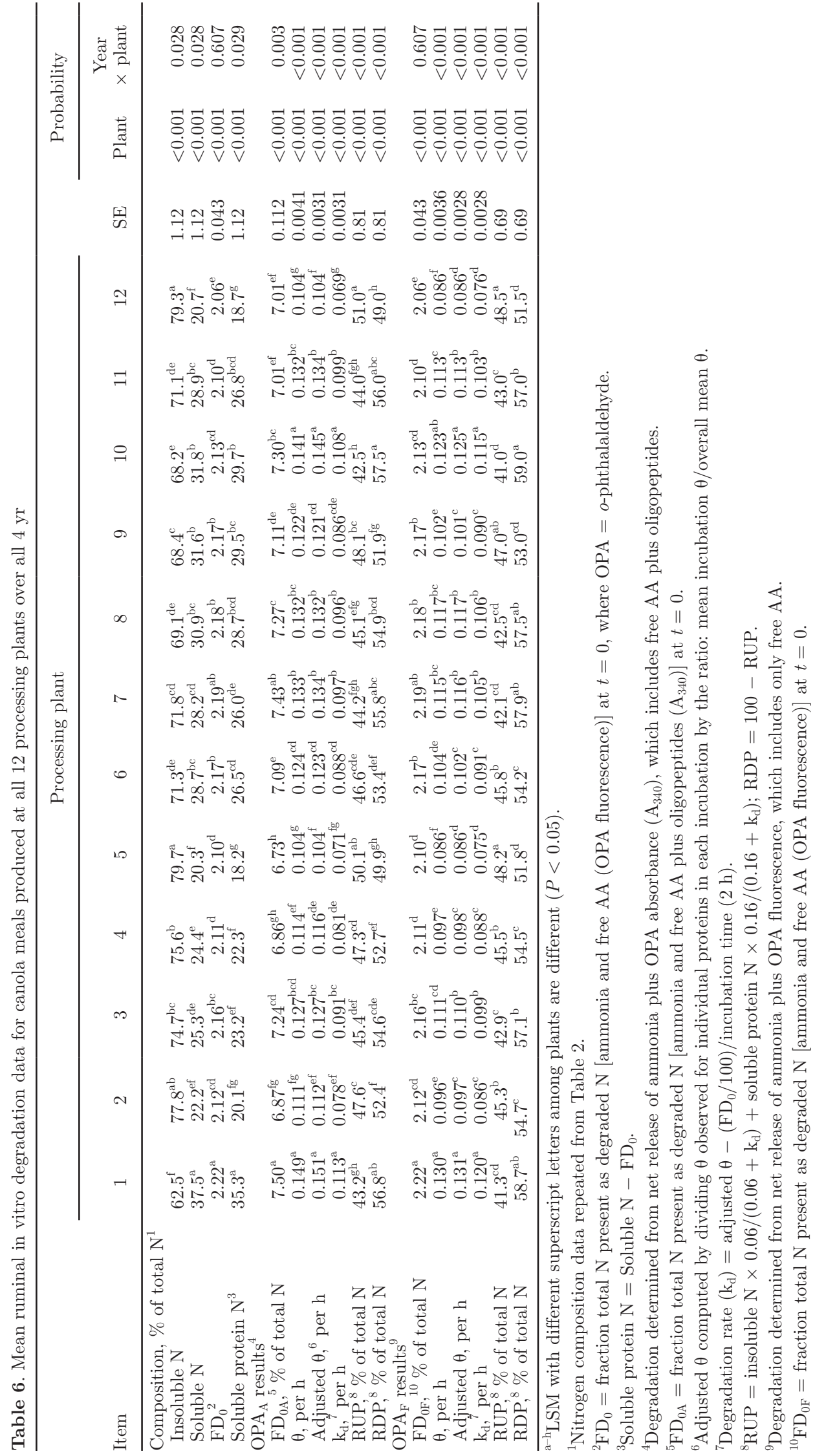


Table 7. Estimates of proportions of total variance (\%) contributed by sources of variation in statistical model ${ }^{1}$

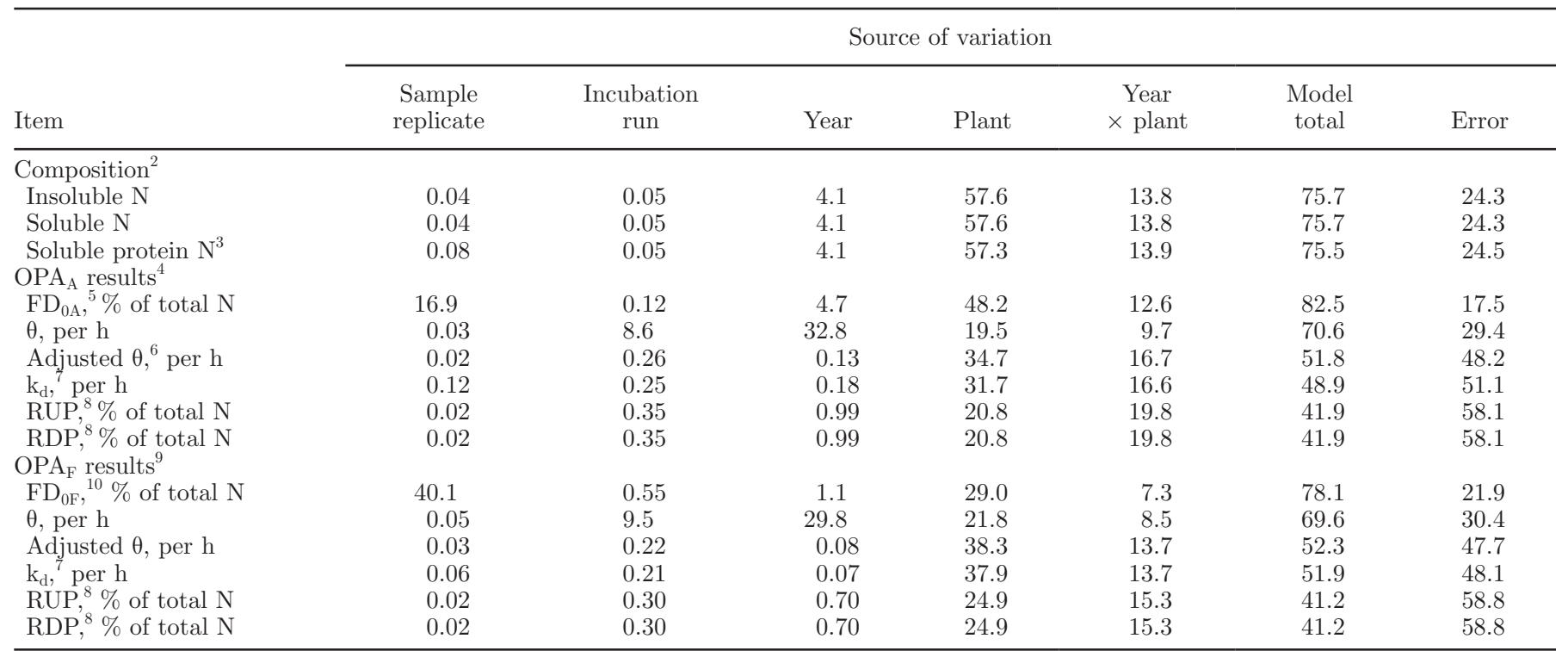

${ }^{1}$ Proportions of total variance computed by dividing type-3 sums of squares for each source of variation by the total type-3 sums of squares determined in an overall SAS GLM analysis of these items.

${ }^{2}$ Nitrogen composition data repeated from Table 2.

${ }^{3}$ Soluble protein $\mathrm{N}=$ soluble $\mathrm{N}-\mathrm{FD}_{0}$.

${ }^{4}$ Degradation determined from net release of ammonia plus o-phthalaldehyde (OPA) absorbance $\left(\mathrm{A}_{340}\right)$, which includes free AA plus oligopeptides.

${ }^{5} \mathrm{FD}_{0 \mathrm{~A}}=$ fraction total $\mathrm{N}$ present as degraded $\mathrm{N}$ [ammonia and free AA plus oligopeptides $\left(\mathrm{A}_{340}\right)$ ] at $t=0$.

${ }^{6}$ Adjusted $\theta$ computed by dividing $\theta$ observed for individual proteins in each incubation by the ratio: mean incubation $\theta$ /overall mean $\theta$.

${ }^{7}$ Degradation rate $\left(\mathrm{k}_{\mathrm{d}}\right)=$ adjusted $\theta-\left(\mathrm{FD}_{0} / 100\right) /$ incubation time $(2 \mathrm{~h})$.

${ }^{8} \mathrm{RUP}=$ insoluble $\mathrm{N} \times 0.06 /\left(0.06+\mathrm{k}_{\mathrm{d}}\right)+$ soluble protein $\mathrm{N} \times 0.16 /\left(0.16+\mathrm{k}_{\mathrm{d}}\right) ; \mathrm{RDP}=100-\mathrm{RUP}$.

${ }^{9}$ Degradation determined from net release of ammonia plus OPA fluorescence, which includes only free AA.

${ }^{10} \mathrm{FD}_{0 \mathrm{~F}}=$ fraction total $\mathrm{N}$ present as degraded $\mathrm{N}$ [ammonia and free AA (OPA fluorescence)] at $t=0$.

ruminal escape with minimal loss of intestinal digestibility. Moreover, greater RUP appears to be supplied by CM produced by some crushing plants than by other CM crushing plants.

\section{CONCLUSIONS}

Effects of production year and processing plant on chemical composition and ruminal in vitro protein degradation were assessed using a large set of CM samples collected from 12 Canadian crushing plants over 4 yr. Overall mean CM protein degradation rate was $0.093 / \mathrm{h}$ and RUP was $45 \%$. Estimates in the same incubations for SSBM and ESBM were, respectively, 0.177 and $0.055 / \mathrm{h}$ for degradation rate and 33 and $56 \%$ for RUP. Small effects of year were present for CM chemical composition, including $\mathrm{N}$ solubility, but differences were partly due to changes in analytical methods over time. However, estimates of CM degradation rate and RUP were not different among processing years. Consistent differences in $\mathrm{CM}$ chemical composition, degradation rate, and RUP were observed among processing plants.
Regression analysis indicated that soluble $\mathrm{N}$ content explained 40 to $42 \%$ of the variation in ruminal degradation rate of CM protein. These results showed important differences in RUP content and thus MP value of CM produced by different canola crushing plants.

\section{ACKNOWLEDGMENTS}

The authors gratefully acknowledge the of the barn crew at the University of Wisconsin-Madison Dairy Cattle Center and the US Dairy Forage Research Center Farm (Prairie du Sac, WI) for care and feeding of the rumen donor cows; Wendy Radloff, Mary Becker, Eduardo Marostegan de Paula, and Ian Kraus for assisting with sampling and laboratory analyses; Peter Crump of the University of Wisconsin-Madison for assisting with statistical analyses; and the Canola Council of Canada for partial funding of this project.

\section{REFERENCES}

Acharya, I. P., D. J. Schingoethe, K. F. Kalscheur, and D. P. Casper. 2015. Response of lactating dairy cows to dietary protein from 
canola meal or distillers' grains on dry matter intake, milk production, milk composition, and amino acid status. Can. J. Anim. Sci. 95:267-279.

AOAC. 1990. Official Methods of Analysis. 15th ed. Assoc. Off. Anal. Chem., Arlington, VA.

Block, R. J., and K. W. Weiss. 1956. The Amino Acid Handbook. Thomas, Springfield, IL.

Borucki Castro, S. I., L. E. Phillip, H. Lapierre, P. W. Jardon, and R. Berthiaume. 2007. Ruminal degradability and intestinal digestibility of protein and amino acids in treated soybean meal products. J. Dairy Sci. 90:810-822.

Boucher, S. E., C. Pedersen, H. H. Stein, and C. G. Schwab. 2009. Evaluation of the furosine and homoarginine methods for determining reactive lysine in rumen-undegraded protein. J. Dairy Sci. 92:3951-3958.

Brennan, R. F. 2016. Effect of time of application and amount of nitrogen fertilizer on seed yield and concentration of oil in canola (Brassica napus). J. Plant Nutr. 39:337-347.

Brito, A. F., and G. A. Broderick. 2007. Effects of feeding different protein supplements on milk production and nutrient utilization in dairy cows. J. Dairy Sci. 90:1816-1827.

Brito, A. F., G. A. Broderick, and S. M. Reynal. 2007. Effects of different protein supplements on omasal nutrient flow and microbial protein synthesis in lactating dairy cows. J. Dairy Sci. 90:18281841.

Broderick, G. A. 1987. Determination of protein degradation rates using a rumen in vitro system containing inhibitors of microbial nitrogen metabolism. Br. J. Nutr. 58:463-475.

Broderick, G. A., and M. K. Clayton. 1992. Rumen protein degradation rates estimated by nonlinear regression analysis of MichaelisMenten in vitro data. Br. J. Nutr. 67:27-42.

Broderick, G. A., A. P. Faciola, and L. E. Armentano. 2015. Replacing dietary soybean meal with canola meal improves production and efficiency of lactating dairy cows. J. Dairy Sci. 98:5672-5687.

Broderick, G. A., D. B. Ricker, and L. S. Driver. 1990. Expeller soybean meal and corn by-products versus solvent soybean meal for lactating dairy cows. J. Dairy Sci. 73:453-462.

Broderick, G. A., P. Uden, M. L. Murphy, and A. Lapins. 2004. Sources of variation in rates of in vitro ruminal protein degradation. J. Dairy Sci. 87:1345-1359.

Broderick, G. A., R. J. Wallace, and N. McKain. 1988. Uptake of small neutral peptides by mixed rumen microorganisms in vitro. J. Sci. Food Agric. 42:109-118.

Chen, G., C. J. Sniffen, and J. B. Russell. 1987. Concentration and estimated flow of peptides from the rumen of dairy cattle: Effects of protein quantity, protein solubility, and feeding frequency. J. Dairy Sci. 70:983-992.

Choi, C. W., A. Vanhatalo, and P. Huhtanen. 2003. Effects of type of grass silage and level of concentrate on the flow of soluble nonammonia nitrogen entering the omasum of dairy cows. J. Anim. Feed Sci. 12:3-22.

Classen, H. L., R. W. Newkirk, and D. D. Maenz. 2004. Effects of conventional and novel processing on the feed value of canola meal for poultry. Pages 1-16 in Proc. Aust. Poult. Sci. Symp. The Poultry Research Foundation, University of Sydney, Sydney, NSW, Australia.

Colombini, S., G. A. Broderick, and M. K. Clayton. 2011. Effect of quantifying peptide release on ruminal protein degradation determined using the inhibitor in vitro system. J. Dairy Sci. 94:19671977.

Craig, W. M., and G. A. Broderick. 1981. Effect of heat treatment on true digestibility in the rat, in vitro proteolysis and available lysine content of cottonseed meal protein. J. Anim. Sci. 52:292-301.

Faldet, M. A., and L. D. Satter. 1991. Feeding heat-treated full fat soybeans to cows in early lactation. J. Dairy Sci. 74:3047-3054.

Faldet, M. A., L. D. Satter, and G. A. Broderick. 1992. Determining optimal heat treatment of soybeans by measuring available lysine chemically and biologically with rats to maximize protein utilization by ruminants. J. Nutr. 122:151-160.
Friedman, M. 1996. Food browning and its prevention: An overview. J. Agric. Food Chem. 44:631-653.

Hickling, D. 2008. Maximized utilization of canola co-products in livestock industry. Pages 3-14 in Proc. 29th Western Nutrition Conference, Edmonton, AB, Canada. University of Alberta, Edmonton, $\mathrm{AB}$, Canada.

Hintz, R. W., D. R. Mertens, and K. A. Albrecht. 1996. Effects of sodium sulfite on recovery and composition of detergent fiber and lignin. J. AOAC Int. 79:16-22.

Huhtanen, P., M. Hetta, and C. Swensson. 2011. Evaluation of canola meal as a protein supplement for dairy cows: A review and a metaanalysis. Can. J. Anim. Sci. 91:529-543.

Licitra, G., T. M. Hernandez, and P. J. Van Soest. 1996. Standardization of procedures for nitrogen fractionation of ruminant feeds. Anim. Feed Sci. Technol. 57:347-358.

Mahler, H. R., and E. H. Cordes. 1966. Biological Chemistry. Harper and Row, New York, NY.

Martineau, R., D. R. Ouellet, and H. Lapierre. 2013. Feeding canola meal to dairy cows: A meta-analysis on lactational responses. J. Dairy Sci. 96:1701-1714.

Maxin, G., D. R. Ouellet, and H. Lapierre. 2013a. Ruminal degradability of dry matter, crude protein, and amino acids in soybean meal, canola meal, corn, and wheat dried distillers grains. J. Dairy Sci. 96:5151-5160.

Maxin, G., D. R. Ouellet, and H. Lapierre. 2013b. Effect of substitution of soybean meal by canola meal or distillers grains in dairy rations on amino acid and glucose availability. J. Dairy Sci. 96:7806-7817.

McCartney, C. A., R. Scarth, P. B. E. McVetty, and J. K. Daun. 2004. Genotypic and environmental effects on saturated fatty acid concentration of canola grown in Manitoba. Can. J. Plant Sci. 84:749-756.

McDougall, E. I. 1948. Studies on ruminant saliva. I. The composition and output of sheep's saliva. Biochem. J. 43:99-109.

Moshtaghi Nia, S. A., and J. R. Ingalls. 1995. Influence of moist heat treatment on ruminal and intestinal disappearance of amino acids from canola meal. J. Dairy Sci. 78:1552-1560.

Mutsvangwa, T., D. Kiran, and S. Abeysekara. 2016. Effects of feeding canola meal or wheat dried distillers grains with solubles as a major protein source in low- or high-crude protein diets on ruminal fermentation, omasal flow, and production in cows. J. Dairy Sci 99:1216-1227.

Newkirk, R. 2009. Canola Meal: Feed Industry Guide. 4th ed. Canadian International Grains Institute, Winnipeg, MB, Canada.

Newkirk, R. W., H. L. Classen, T. A. Scott, and M. J. Edney. 2003. The digestibility and content of amino acids in toasted and nontoasted canola meals. Can. J. Anim. Sci. 83:131-139.

NRC. 2001. Nutrient Requirements of Dairy Cattle. 7th rev. ed. Natl. Acad. Sci., Washington, DC.

Pritchard, F. M., H. A. Eagles, R. M. Norton, P. A. Salisbury, and M. Nicolas. 2000. Environmental effects on seed composition of Victorian canola. Aust. J. Exp. Agric. 40:679-685.

Roth, M. 1971. Fluorescence reaction of amino acids. Anal. Chem. $43: 880-882$.

SAS Institute. 2013. SAS ${ }^{\circledR}$ 9.4-Guide to Software Updates. SAS Inst. Inc., Cary, NC.

Segal, I. 1976. Biochemical Calculations. 2nd ed. John Wiley \& Sons, New York, NY

Swanepoel, N., P. H. Robinson, and L. J. Erasmus. 2014. Determining the optimal ratio of canola meal and high protein dried distillers grain protein in diets of high producing Holstein dairy cows. Anim. Feed Sci. Technol. 189:41-53.

Thacker, P. A., and R. W. Newkirk. 2005. Performance of growingfinishing pigs fed barley-based diets containing toasted or nontoasted canola meal. Can. J. Anim. Sci. 85:53-59.

Van Soest, P. J., J. B. Robertson, and B. A. Lewis. 1991. Methods for dietary fiber, neutral detergent fiber, and nonstarch polysaccharides in relation to animal nutrition. J. Dairy Sci. 74:3583-3597.

Waldo, D. R., L. W. Smith, and E. L. Cox. 1972. Model of cellulose disappearance from the rumen. J. Dairy Sci. 55:125-129. 